\title{
Critical Analysis of Prohibition of Anti-Competitive Trade Practices in Ethiopia: The Case of Arbaminch Town, Southern Ethiopia
}

\author{
Bogale Anja Abba, Yared Kefyalew Demarso \\ School of Law, Wolaita Sodo University, Wolaita Sodo, Ethiopia \\ Email: bogawassa@gmail.com,yaredoo2@gmail.com
}

How to cite this paper: Abba, B. A., \& Demarso, Y. K. (2021). Critical Analysis of Prohibition of Anti-Competitive Trade Practices in Ethiopia: The Case of Arbaminch Town, Southern Ethiopia. Beijing Law Review, 12, 215-227.

https://doi.org/10.4236/blr.2021.121013

Received: January 9, 2021

Accepted: March 22, 2021

Published: March 25, 2021

Copyright (c) 2021 by author(s) and Scientific Research Publishing Inc. This work is licensed under the Creative Commons Attribution International License (CC BY 4.0).

http://creativecommons.org/licenses/by/4.0/

\begin{abstract}
In a free market context, trade competition signifies a state of affairs where in sellers compete with each other to attract buyers with a view to maximizing their sales, profits and market share. Trade competition laws and policies are among the tools that can be used to bring about efficient workings of markets and alleviate market failures. This research sought to explore prohibition of anti-competitive trade practices in Ethiopia in general and particularly in Arbaminch town, Southern Ethiopia. The research has employed doctrinal approach and the data collected were analyzed qualitatively. Both primary and secondary sources of data were used. The findings of the research indicated that there is lack of effective enforcement of the existing law in the study area. There are also anti-competitive trade practices remained uncovered by the law. The current trade competition law of the country needs revision. There is also a need to establish law enforcement bodies and independent adjudicative organs at regional level including in the study area.
\end{abstract}

\section{Keywords}

Trade Competition, Anti-Competitive Practices, Businessperson

\section{Introduction}

Despite the existence of different market models in the free market context, trade competition signifies a state of affairs where in sellers compete with each other to attract buyers with a view to maximizing their sales, profits and market share (Merso et al., 2009). Trade competition is also defined in different manner in corporate world while comparing its definition in market economy. It is taken as a process whereby firms strive against each other to secure customers for their 
products (Haroye, 2008).

Trade competition can bring benefits to market efficiency, such as encouraging firms to improve productivity, reduce prices and innovate, while rewarding producers with profits and consumers with lower prices, higher quality and wider choice than the case in less competitive market (UNCTAD, 2018). Thus, trade competition is considered as cornerstone for free market economy. Trade competition laws and policies are among the tools that can be used to bring about efficient workings of markets and help to alleviate market failures (UNCTAD, 2018). They also intervene when businessperson or firm competes to take place of its rival or tries to eliminate the competitor, so that the public at large and the business community can ultimately benefit from predictable and enforceable rules of conduct within the framework of free competition (Haroye, 2008).

Trade practice may adopt either fair or unfair methods. Fair trade competition is expressed through businessperson's or firms effort in terms of innovation, choice, quality, and service to attract their customers while unfair competition is expressed through the adoption of restrictive business practices such as predatory pricing, exclusive dealing, forming cartels and the like rather than focusing on innovation, choice, quality and services (Haroye, 2008). So, trade practice is desired to be fair though it is achieved through different factors.

Generally, the main objective of trade competition laws is maintaining and enhancing market competition by addressing restrictive business practices and market structures that significantly lessen competition (Merso et al., 2009). Besides, for the consideration of economic efficiency, governments do have other socioeconomic and even political objectives, and priorities they wish to promote through competition laws, such as consumer welfare and development, ensuring employment, protecting small businesses, and promoting export (Merso et al., 2009). Existing studies have shown that prohibiting anti-competitive trade practices and behavior is the main means, among others, to enforce consumer protection besides promotion of competition in a market economy.

Trade competition and consumer protection laws maintain the process of trade competition between enterprises and try to remedy behavioral and structural problems in order to re-establish effective competition in the market. It also concerns with the nature of consumer transactions to improve market conditions for effective exercise of consumer choice (Elias, 2015). Though the two disciplines focus on different market failures and offer different remedies, they both aim at maintaining well-functioning competitive market that promotes consumer welfare. The effectiveness of both laws is, inter alia, determined by the quality of their enforcement framework and practical application. Therefore, maintaining both with a well-designed legal, institutional and practical application needs due attention.

The adoption of a trade competition law by different countries, especially developing and transitional economies, has experienced an unprecedented growth 
since 1990s (Denebo, 2015). Trade competition is of overwhelming important for the functioning of market economies. It is this deriving force that facilitates countries of the world to have a competition law and enforcing institution. The Ethiopian government has introduced a new Trade Competition and Consumer Protection Proclamation No. 813/2013. The proclamation included comprehensive amendments in order to promote commercial activities to be conducted in accordance with the appropriate practice based on the free market economy policy of the country, to protect business community from anti-competitive and unfair market practices, and consumers from misleading market conducts among others (Trade Competition and Consumer Protection Proclamation of the Federal Democratic Republic of Ethiopia, FDRE, 2014).

Even though the Ethiopian government has pledged to enforce free market economic policy, existing studies suggest that the level of competition in Ethiopia has been very low, there has been the prevalence of anti-competitive practices, especially anti-competitive agreements have been identified as the most prevalent anti-competitive practices that affect consumers negatively (Elias, 2015). No cases on anti-competitive agreements have been entertained by the Trade Competition and Consumer Protection Authority since its establishment and other organ except for some cases of hoarding against which the Ministry of Trade and some of the regional Trade and Industry Bureaus have taken measures (Elias, 2015).

Due to lack of decentralization of consumer protection enforcement and other related problems, there is no clear mandate given to regional governments to enforce anti-competitive trade laws. There is lack of representation of private sector and other stakeholders including consumers in Trade Competition and Consumer Protection Authority. Therefore, lack of research conducted on the current research topic specifically initiated the researcher to conduct this research in the study area.

There are gaps in the law and the existing law is not effectively enforced. The law fails to exhaustively state anti-competitive practices. Despite the enactment of the law, the law is not effectively implemented. It is clearly observed that there is violation of the law by the businesspersons in the study area. There is also a gap regarding establishment of enforcement organs at the regional level including the study area.

\section{The Research Method}

The study has employed both primary and secondary sources of data. The main source of primary data includes trade competition and consumer protection proclamation no. 813/2013 and other relevant laws. The secondary data include books, journals, published and unpublished materials. This study has employed descriptive research design. Accordingly, the data collected were qualitatively analyzed in order to assess the legal and institutional framework of trade competition in the study area. The researchers gathered valid, relevant and reliable data 
and analyzed descriptively in order to achieve the intended research objectives.

\section{Literature Review}

\subsection{The General Overview of Trade Competition}

The fact that trade competition is beneficial in free market economy doesn't mean that it should be free from any regulation. Market competition is regulated for different reasons. Due to limited resources and unlimited wants and needs, every society is expected to address resource allocation (what goods to produce), production (how to produce the goods), and distribution (who receives the goods produced) issues (Merso et al., 2009). Pure free market is an economic model in which markets answer all questions related to allocation issues and leaves no space for the role of the government in making decisions on it. The role of the government is rather limited to the enforcement of property rights and contracts. Thus, pure free market model fails to provide some essential components of real market which includes the production of public goods (like national defense), merit goods (like education and health care), market externalities, and institutional costs (Merso et al., 2009).

Trade competition policy refers to governmental measures that directly affect the behavior of enterprises and the structure of industry (Merso et al., 2009). It also covers a whole raft of executive policies and approaches. In this sense trade competition policy could be understood to include two components: economic policies that enhance competition in local and national markets; and, laws designed to regulate anti-competitive business practices by firms and unnecessary government intervention in the market (Merso et al., 2009). Policies with implications for market competition include deregulation and privatization, trade liberalization, consumer protection, intellectual property, industrial policy, government procurement, labor, and taxation. In addition, sector-specific policies in various areas, such as health, electricity, telecommunications, financial services etc., also affect market competition (Merso et al., 2009).

Trade competition law is a major component of competition policy and its scope may vary from jurisdiction to jurisdiction. It is generally understood as a tool designed to control and to prohibit anti-competitive practices and tendencies that might risk competition (Merso et al., 2009). Trade competition laws mainly aims at maintaining and enhancing market competition by addressing restrictive business practices and regulate market structures that significantly lessen competition (Merso et al., 2009). Generally, it targets at economic efficiency and overall social welfare.

\subsection{The Legal and Institutional Framework of Trade Competition in Ethiopia}

\subsubsection{The Legal Framework}

The history of trade competition law in Ethiopia was traced back to the era of imperial government of 1960s. The first attempt during this time was to control 
competition through private law which was the then enacted Commercial Code of Ethiopia of 1960. Later on, the imperial regime directly recognized trade competition by enacting the Unfair Trade Practice Decree in 1963. There was no separate institution established in order to entertain unfair trade practices, the task was left to the ordinary courts.

Due to the political system it followed, there was no trade competition policy and law during the military government. The system at the time was socialist and thinking of trade competition was impractical. There was no trade competition law during the transitional period from 1991-1995. There was, however, a tacit application of the rules on unfair trade competition under the Commercial Code (The Commercial Code of the Empire of Ethiopia, 1960). Later, Trade Competition and Consumers Protection law; Trade Registration and Licensing Proclamation No. 329/2003 and Trade Practice and Consumer Protection Proclamation No. 685/2010 are introduced to amend the then 1965 Commercial Code of Ethiopia.

The Ethiopian government has introduced a new Trade Competition and Consumer Protection Proclamation No. 813/2013 which makes comprehensive amendments of previous proclamation. The proclamation has introduced in order to promote commercial activities to be conducted in accordance with the appropriate practice based on the free market economy policy of the country, to protect business community from anti-competitive and unfair market practices, and consumers from misleading market conducts among others (Trade Competition and Consumer Protection Proclamation of the Federal Democratic Republic of Ethiopia, FDRE, 2014). The law provides various anti-competitive trade practices. Some of these include unfair trade competition, Anti-competitive Agreements/Concerted Practices and Decisions, abuse of market dominance and anti-competitive merger, Predatory pricing (Desalegn Adera, 2011).

\subsubsection{Anti-Competitive Trade Practices}

1) Unfair Trade Practices: The terms unfair competition and unfair trade practices are often used interchangeably in different legal system while some legal systems make distinctions between the two. In Ethiopia too the terms are used interchangeably. Unfair competition refers to those actions of firms that cause an economic injury to another firm, through a deceptive or wrongful business practices (Merso et al., 2009). It also refers to those actions which are meant to confuse consumers as to the sources of the product. It is limited to misleading advertisement and false representation. Unfair trade practices, on the other hand, comprise all other forms of unfair competition.

The Trade Competition and Consumer Protection Proclamation No. 813/2013 of Ethiopia prohibit unfair trade competition which is dishonest, misleading or deceptive, and harms or is likely to harm the business interest of a competitor. Those acts which are deemed to be acts of unfair competition are also listed under article 8 sub article 2 of above mentioned proclamation. However, there is no regulation issued to address similar acts not mentioned in the proclamation and 
left to be enumerated in the regulation. So, acts of unfair competition are only limited to the listed activities. It does not include prohibition of restrictive trade practices such as predatory pricing. Predatory pricing (also called undercutting) is a pricing strategy where a product or service is set at a very low price, intending to drive competitors out of the market, or create barriers to entry for potential new competitors. There is also prevalence of unfair trade practices such as false allegation that discredits another businessperson's activity under current study area.

2) Anti-competitive Agreements/Concerted Practices and Decisions: Explicit or implicit agreements among businesspersons with the effect of avoiding or limiting trade competition in the market may take place during transactions or relationships between businesspersons (Merso et al., 2009). Concerted practices refer to a form of coordination between enterprises that has not yet reached the point where there is a contract in the true sense of the word. However, in practice consciously it substitutes a practical cooperation for the risks of competition.

Restrictive agreements may be made between competing firms at the same stage of the production process or those at different stages. Agreements between two or more firms at the same level are known as horizontal agreements or, where inherently anticompetitive, cartels. Agreements between firms at different levels on the other hand are designated vertical agreements or "vertical restraint" (Merso et al., 2009).

Horizontal agreements are prohibited if agreements, concerted practices and decisions have the effect of preventing or significantly lessening competition. It involves directly or indirectly fixing price; collusive tendering; allocating customers, or marketing territories or production or sale by quota (Trade Competition and Consumer Protection Proclamation of the Federal Democratic Republic of Ethiopia, FDRE, 2014). On the other hand, agreement between businesspersons in vertical relationship involves setting minimum resale price (Trade Competition and Consumer Protection Proclamation of the Federal Democratic Republic of Ethiopia, FDRE, 2014). Even though both horizontal and vertical agreements are prohibited as mentioned above, data collected under current study area reveals the prevalence of a number of anti-competitive agreements such as price fixation/cartel like arrangements, hoarding and price gouging, and exclusive distribution arrangements.

3) Abuse of Market Dominance:

Abuse of dominance takes place by actions of a businessperson already dominant in a market that significantly lessens competition in that particular market (Merso et al., 2009). To say there is anticompetitive practice, there should be abuse of market dominance. Thus it does not mean a mere dominant market position.

It is prohibited to abuse, openly or dubiously, dominance by a dominant businessperson either himself or acting together with others (Trade Competition and Consumer Protection Proclamation of the Federal Democratic Republic of 
Ethiopia, FDRE, 2014). A businessperson is considered as dominant when he has the actual capacity to control prices or other conditions of commercial negotiations or eliminate or utterly restrain competition in the relevant market (Trade Competition and Consumer Protection Proclamation of the Federal Democratic Republic of Ethiopia, FDRE, 2014). A dominant position in a market is assessed taking in to account the share of a businessperson or his capacity to set barriers against the entry of others in to the market, other similar factors, or combination of them (Trade Competition and Consumer Protection Proclamation of the Federal Democratic Republic of Ethiopia, FDRE, 2014). The condition for the assessment of market to determine dominant position is the market that comprises the goods and services that actually compete with each other or goods and services that replace each other (Trade Competition and Consumer Protection Proclamation of the Federal Democratic Republic of Ethiopia, FDRE, 2014).

4) Merger: Merger in a wider sense and in competition law includes amalgamation, pooling of resources in joint venture, acquisition of another enterprise's shares, voting rights, assets, or control over that enterprises (Trade Competition and Consumer Protection Proclamation of the Federal Democratic Republic of Ethiopia, FDRE, 2014). Basically, merger is created when one company acquires the assets and liabilities of another company, and causing that other company to cease to exist as an independent entity. Merger occurs when two or more business organizations previously having independent existence amalgamate or when such business organizations pool the whole or part of their resources for the purpose of carrying on a certain commercial activity (Trade Competition and Consumer Protection Proclamation of the Federal Democratic Republic of Ethiopia, FDRE, 2014). The same proclamation also provides that merger occurs when a person or group of persons directly or indirectly acquires shares, securities or assets of a business organization or taking control of the management of the business of another person through purchase or any other means. An agreement or arrangement of merger that causes or is likely to cause a significant adverse effect on trade competition is prohibited in the same proclamation.

Mergers can be categorized as horizontal, vertical and conglomerate. Horizontal mergers take place between two firms that are actual or potential competitors, which sell the same products or close substitutes and it refers to the fact that the two enterprises are at an identical level in the chain of production, Vertical mergers take place between firms at different levels in the chain of production which have an actual or potential buyer-seller relationship while Conglomerate mergers are neither horizontal nor vertical; they neither produce competing products nor are in an actual or potential buyer-seller relationship (Haroye, 2008).

\subsubsection{The Institutional Framework}

There are institutions which are entrusted with the power and duty of implementing trade competition and consumer protection law in Ethiopia. The organs that are established by the Trade Competition and Consumer Protection Proc- 
lamation No. 813/2013 includes: The Federal Trade Competition and Consumer Protection Authority (hereinafter called the "Authority"), Federal Trade Competition and Consumer Protection Appellate Tribunal, Regional Consumer Protection Judicial Organs and Appellate Tribunals, Ministry of Trade (MoT) and Regional Trade and Industry Bureaus (RTBs) and Courts both at federal and regional levels.

\section{1) The Trade Competition and Consumer Protection Authority}

Trade Competition and Consumer Protection Proclamation No. 813/2013 under part IV, establishes the Authority for the enforcement of trade competition law in Ethiopia. The Authority is the primary agency for the enforcement of the law in Ethiopia with an autonomous federal government body having its own legal personality. The authority shall be accountable to the Ministry of Trade (MoT) and shall be governed by the provisions of the trade competition proclamation.

The Authority establishes three organs under the institution. These are trade competition organs for conducting investigation, institution of action (prosecution) and an organ with adjudication power. At the federal level the judicial organ within the competition authority further divided in to two. These are the adjudicative bench of the competition authority and the federal appellate tribunal. The authority is empowered to take appropriate measures to increase market transparency; take appropriate measures to develop public awareness on the provision of the competition proclamation; receive and decide on, merger notifications; and protect consumers from unfair practices of business persons, organize judicial organs with jurisdiction on issues of trade competition and consumer protection; provide support to industrial self-regulation in order to enable various industrial sectors regulate anti-competitive and unfair trade practices; own property, enter into contracts, sue and be sued in its own name; and perform such other related activities conducive for the attainment of its objectives. The proclamation is limited to federal government and there is no separate and independent consumer protection law and independent institutional framework too at regional level including the current study area.

\section{2) The Federal and Regional Courts}

The Proclamation requires the federal and regional courts to organize trade competition and consumer protection divisions to entertain the trade competition and consumer protection adjudications (Trade Competition and Consumer Protection Proclamation of the Federal Democratic Republic of Ethiopia, FDRE, 2014). The courts at federal and regional levels are also empowered to adjudicate and pass decisions on criminal liabilities arising out of the violation of the law. The Federal Appellate Tribunal is granted with appellate jurisdiction. Any party who is aggrieved by the decision of the authority is entitled to appeal to the tribunal within thirty days from the date of the decision by the authority. The Federal Appellate Tribunal passes final decision except for cassation revision by Federal Supreme Court on matters containing basic error of law. However, there 
is no court division organized to entertain the trade competition and consumer protection adjudications under current study area.

Recently, the prosecution and investigation powers of the authority are transferred to two different organs based on the current structural change of the federal government organs. According to article 22(6) and (7) of the federal attorney general establishment proclamation No. 943/2016, prosecution and crime investigation powers are transferred to federal attorney general and federal police commission respectively (Federal Attorney General Proclamation of the Federal Democratic Republic of Ethiopia, FDRE, 2016). So, the authority has no power of prosecution and investigation.

\section{3) The Adjudication Power}

The authority has also been granted with extensive judicial power. It shall have judicial power to take administrative measures and impose penalties on a business person; and order payment of compensation in accordance with the relevant laws to business persons victimized by acts of unfair competition committed in violation of the provisions of part two of the proclamation (Trade Competition and Consumer Protection Proclamation of the Federal Democratic Republic of Ethiopia, FDRE, 2014). It also exercises its judicial power by ordering compensation in accordance with the relevant laws to consumers victimized in violation of consumers' protection provisions stipulated under part three of the same proclamation.

The Authority has a power to take administrative measures such as ordering discontinuance of the act pronounced unfair; taking any other appropriate measure that enables to reinstate the victims competitive position; and the suspension or revocation of the business license of the offender (Trade Competition and Consumer Protection Proclamation of the Federal Democratic Republic of Ethiopia, FDRE, 2014). It may also order any person to furnish information and submit documents that may require; summon any witness to appear and testify; execution of orders and decisions of the adjudicative benches; order the police or any other appropriate organ; and order the attachment, seizure and sale of goods. Any person aggrieved by the decision of the Authority to prohibit merger or to revoke merger approval or to ban a commercial advertisement or by any decision including anti-competitive trade practice of an adjudicative bench of the Authority may appeal to the Federal Appellate Tribunal within thirty days from the date of decision. Even though the law envisages the establishment of a regional consumer protection judicial organ, it does not give administrative power to the organ; nor does it give the power to investigate and institute action against violators.

\section{4) The Federal Trade Competition and Consumer Protection Appellate Tribunal}

The Federal Appellate Tribunal upon examining an appeal submitted to it confirm, reverse or vary the decision, or remand the case with necessary instructions to the Authority or the adjudicative bench of the Authority. The decision 
of the Federal Appellate Tribunal on the appeal submitted to it shall be final, provided, however, that the party that claims the existence of mistake on question of law regarding a decision passed may lodge an appeal to the Federal Supreme Court within thirty days from the date of the decision. The Appellate Tribunal's Structural attachment to the Authority and whether or not it is structured with general courts of the Federal Government is not clearly defined. The Tribunal is also financially dependent on the Authority but it is separately established federal trade competition judicial organ.

There are some issues still not covered by the proclamation. One of this is regarding organs dealing with trade competition organs in the regional states. In the regions, there is no independent judicial organ established to adjudicate trade competition disputes in the regional states. Since prosecution and investigation power of the authority transferred to other organs the fate of adjudicative power of the authority is not settled. It is not clearly settled whether such power remain in the hands of the authority or transferred to ordinary courts.

\section{Summary of the Research}

Trade competition is taken as a process whereby firms strive against each other to secure customers for their products. Trade competition is considered as cornerstone for free market economy. Competition laws and policies are among the tools that can be used to bring about efficient workings of markets and helps to alleviate market failures. Though market competition is important in free market economy, it is regulated for different reasons. Due to limited resources and unlimited wants and needs, every society is expected to address resource allocation (what goods to produce), production (how to produce the goods), and distribution (who receives the goods produced) issues.

The competition law is a major component of competition policy and its scope may vary from jurisdiction to jurisdiction. It is generally understood as a tool designed to control and to prohibit anti-competitive practices and tendencies that might risk competition. Competition laws mainly aims at maintaining and enhancing market competition by addressing restrictive business practices and regulate market structures that significantly lessen competition.

The adoption of a trade competition law by different countries, especially developing and transitional economies has experienced an unprecedented growth since 1990s. The history of competition law in Ethiopia was traced back to the era of imperial government of 1960s. Due to the political system it followed, there was no competition policy and law during the military government. The Ethiopian government introduced a new Trade Competition and Consumer Protection Proclamation No. 813/2013.

The proclamation includes unfair trade practices, anti-competitive agreements/concerted practices and decisions, abuse of market dominance and merger as anti-competitive trade practices. The terms unfair competition and unfair trade practices are often used interchangeably in Ethiopia like many other legal 
systems. Unfair trade competition refers to those actions of firms that cause an economic injury to another firm, through a deceptive or wrongful business practices. Unfair trade practices, on the other hand, comprise all other forms of unfair competition. Concerted practices refer to a form of coordination between enterprises that has not yet reached the point where there is a contract in the true sense of the word. However, in practice consciously it substitutes a practical cooperation for the risks of competition. Abuse of dominance takes place by actions of a businessperson already dominant in a market that significantly lessens competition in that particular market. Merger is created when one company acquires the assets and liabilities of another company, and causing that other company to cease to exist as an independent entity.

Trade Competition and Consumer Protection Proclamation No. 813/2013 under part IV, establishes the Trade Competition and Consumer Protection Authority for the enforcement of competition law in Ethiopia. The Authority establishes three organs under the institution. These are the competition organ for conducting investigation, institution of action (prosecution) and an organ with adjudication power. However, the prosecution and investigation powers of the authority are transferred to federal attorney general and federal police commission respectively. The fate of adjudicative benches of the authority remained unsettled. The proclamation has limited establishment of enforcement organs only at federal level and gives discretion for regional states to establish their own separate organs. There is no independent institutional framework at regional level including in the current study area.

The Proclamation requires the federal and regional courts to organize trade competition and consumer protection divisions to entertain trade competition and consumer protection adjudications. However, there is no court divisions organized to entertain the trade competition and consumer protection adjudications in the study area. Here, the prosecutions and investigations are made by regional police and public prosecutors.

\section{Concluding Remarks}

This research tried to investigate prohibition of anti-competitive trade practices in the study area. In Ethiopia, the current Trade Competition and Consumer Protection Proclamation No. 813/2013 is adopted in order to regulate anti-competitive trade practices. The proclamation has established enforcement organs and adjudicative bodies at federal level. There is no separate and independent trade competition and consumer protection institutional framework at regional level including in the current study area. Ethiopia prohibits unfair trade competition which is dishonest, misleading or deceptive, and harms or is likely to harm the business interest of a competitor.

Those acts which are deemed to be acts of unfair competition are also listed under the proclamation. Similar acts not mentioned in the proclamation left to be enumerated in the regulation to be issued by the Council of Ministers. How- 
ever, there is no regulation issued yet. So, acts of unfair trade competition are only limited to the listed activities. It does not include prohibition of restrictive trade practices, such as predatory pricing. The law needs amendment in these regards. There is also prevalence of unfair trade practices, such as false allegation that discredits another businessperson's activity under current study area.

The proclamation requires the federal and regional courts to organize trade competition and consumer protection divisions to entertain the trade competition and consumer protection adjudications. However, there is no court division organized to entertain the trade competition and consumer protection adjudications under current study area. Even though both horizontal and vertical agreements are prohibited, under current study area, there is prevalence of a number of anti-competitive agreements, such as price fixation/cartel like arrangements, hoarding and price gouging, and exclusive distribution arrangements.

Even though the law gives regional states to establish consumer protection judicial organ, there is no organ established at the regional level. The regional governments should establish enforcement organs and separate adjudicative benches even within the regular courts. There is also lack of awareness of the society regarding the anti-competitive practices; the governing law and enforcement organs in the study area. So, there is a need to conduct awareness creation by the government.

\section{Conflicts of Interest}

The authors declare no conflicts of interest regarding the publication of this paper.

\section{References}

Adera, D. (2011). The Legal and Institutional Framework for Consumer Protection in Ethiopia. LL.M Thesis, Addis Ababa: Addis Ababa University.

Denebo, D. (2015). Evaluating Issues Related with Consolidation of Investigation, Prosecution and Adjudication Powers under the Ethiopian Competition Authority: A Comparative Analysis.

Elias, T. (2015). Gaps and Challenges in the Enforcement Framework for Consumer Protection in Ethiopia. Mizan Law Review, 9, 83-107. https://doi.org/10.4314/mlr.v9i1.3

Federal Attorney General Proclamation of the Federal Democratic Republic of Ethiopia, FDRE (2016). Federal Democratic Republic of Ethiopia, Proclamation No. 943/2016 Federal Attorney General Proclamation of the Federal Democratic Republic of Ethiopia,Addis Ababa.

Haroye, H. (2008). Competition Policies and Laws: Major Concepts and an Overview of Ethiopian Trade Practice Law. Mizan Law Review, 2, 33-51.

https://doi.org/10.4314/mlr.v2i1.55619

Merso, F. M. et al. (2009). Review of the Legal and Institutional Framework for Market Competition in Ethiopia. Private Sector Development Hub/AA Chamber of Commerce and Sectoral Associations.

Trade Competition and Consumer Protection Proclamation of the Federal Democratic Republic of Ethiopia, FDRE (2014). Federal Democratic Republic of Ethiopia, Procla- 
mation No. 813/2013 Trade Competition and Consumer Protection Proclamation of the Federal Democratic Republic of Ethiopia, Addis Ababa.

UNCTAD (2018). Manual on Consumer Protection, UNCTAD/DITC/CPLP/2017/1/Corr.1. 